\section{Summary}

One hundred and seven patients, 46 males and 61 females, who were attending for treatment of hypertension were assessed from the standpoint of the presence or absence of evidence of coronary artery disease. An oral glucose-tolerance test was carried out on each patient. It was found that of all patients in the study group with evidence of coronary artery disease there were $35 \%$ with abnormal glucose tolerance whereas in those patients with no symptoms of coronary disease there were only $16 \%$ with abnormal tests. A higher percentage of patients with abnormal glucose tolerance was also noted in those in whom the only evidence of ischaemic heart disease was STsegment depression in the electrocardiogram after exercise. The basal blood-pressure was not significantly different between those patients with and those without evidence of ischaemic heart disease.

The helpful criticism and encouragement of Sir Horace Smirk in the preparation of this paper are gratefully acknowledged. My thanks are also due to the Biochemistry Department of the Otago Medical School for carrying out the biochemical investigation, and to colleagues for referring patients for investigation; also to $\mathrm{Mr}$. G. F. Spears for statistical assistance.

\section{REFERENCES}

College of General Practitioners (1963). Report of a Working Party, Brit. med. 7., 2, 655 .

Conn, J. W., and Fajans, S. S. (1961). Amer. F. Med., 31, 839.

Dawber, T. R., Kannel, W. B., Revotskie, N., and Kagan, A. (1962). Proc. roy. Soc. Med., 55, 265.

Fearnley, G. R., Chakrabarti, R., and Avis, P. R. D. (1963). Brit. med. f., $1,921$.

Moolten, S. E., Jennings, P. B., and Solden, A. (1963). Amer. F. Cardiol., 11, 290.

Shapiro, A. P., Benedek, T. G., and Small, J. L. (1961). New Engl. f. Med., 265, 1028 .

Sowton, E. (1962). Brit. med. 7., 1, 84.

Vallance-Owen, J., and Ashton, W. L. (1963). Lancet, 1, 1226.

White, P. (1962). Med. Clin. N. Amer., 46, 1177.

\title{
Phenindione Sensitivity
}

\author{
ARTHUR HOLLMAN,* M.D., M.R.C.P. ; H. O. WONG, $†$ M.B., M.R.C.P., M.R.A.C.P.
}

Brit. med. F., 1964, 2, 730-732

Sensitivity reactions to phenindione began to be reported soon after its initial trials in the U.S.A., Canada, and Great Britain, and as early as 1954 Brown and MacMillan, from Toronto, decided to discontinue the use of the drug. They had carried out a randomized trial of four different anticoagulants, and two of the 261 patients treated with phenindione developed agranulocytosis, one case being fatal. Tait (1960) thought it "desirable to use alternative preparations," and Perkins (1962) pointed out that six deaths had been attributed to phenindione sensitivity. The British Medical fournal (1963) contrasted the lack of major toxic effects from the coumarins with the severe reactions sometimes caused by phenindione. There are now 34 papers with reports of severe sensitivity reactions to phenindione, and their authors are listed in the Bibliography. Many of the reactions have been multiple and include fever, rashes (both scarlatiniform and maculo-papular and often intensely pruritic), exfoliative dermatitis, eosinophilia, agranulocytosis, lymphadenopathy, stomatitis, pharyngitis, diarrhoea, steatorrhea, jaundice, and renal damage. This is excluding reports of lone skin rashes even though they may have forced a change to another anticoagulant, as occurred in $2 \%$ of Stafford's (1961) series.

We now report a further two cases in which sensitivity reactions have been associated with the use of phenindione. One had renal damage and one severe stomatitis, and in both a second course of the drug led to a return of the symptoms.

\section{Case Reports}

Case 1.-A 44-year-old tailor had an acute myocardial infarction for which he was treated with phenindione and from which he made a good recovery. Urine examination on admission to and discharge from University College Hospital revealed no abnormality. A maintenance dose of $100 \mathrm{mg}$. of phenindione daily was given and

* Consultant Cardiclogist, University College Hospital, London. t Honorary Registrar, University College Hospital, London. nine weeks after starting treatment oedema of the ankles and a purpuric rash over the legs developed and led to his admission to another hospital. Phenindione was stopped and the oedema and rash subsided. On discharge phenindione was restarted and a rapid return of the symptoms a week later led to his readmission to University College Hospital. Examination showed a fine purpuric rash on the legs and tender swollen ankles. The urine contained $10 \mathrm{~g}$. of protein per litre and microscopy revealed numerous granular and cellular casts and very numerous pus cells. It was sterile on culture. Electrophoresis of the urinary protein revealed a typical glomerular proteinuria with a vast preponderance of albumin. Blood count, blood urea, and excretion pyelogram were all normal Renal biopsy was attempted, but no kidney tissue was obtained. The oedema and purpura subsided rapidly when phenindione was stopped, but three months later moderate proteinuria was still present. Skin-testing was done by injecting $0.1 \mathrm{ml}$. of serum from patients taking phenindione, warfarin, and no drug, but no local reactions occurred.

Case 2.-A 38-year-old cashier was admitted to University College Hospital with an acute pulmonary embolus. He was treated with phenindione and was discharged taking $125 \mathrm{mg}$. daily. Thirtyone days after starting treatment he developed ulcers on the mouth, tongue, and gums which gradually worsened until phenindione was stopped on the 59th day of therapy. Three weeks later phenindione was restarted following the development of a leg-vein thrombosis, and the stomal ulcers recurred three days later. They again subsided when phenindione was withdrawn.

\section{Discussion}

\section{Renal Damage by Drugs}

A variety of drugs have been known to give rise to acute renal failure or to the nephrotic syndrome. The mechanism of the damage is thought to be a direct nephrotoxic effect with some drugs and a hypersensitivity reaction with others, though it is doubtful whether such a clear-cut differentiation can always be maintained. Direct renal damage occurs, for example, with mercury, gold, and potassium chlorate, while, among 
others, hypersensitivity occurs with phenylbutazone, sulphonamides, and phenindione.

The type of renal damage produced by phenindione has varied somewhat, at least in its clinical manifestations, as can be seen from the Table.

The majority of these patients have had a uraemia with proteinuria, but three developed the nephrotic syndrome. Histological evidence is available in only four patients and showed tubular necrosis of varying severity in all, interstitial cellular infiltration in three, and glomerular changes in two. Four of the six uraemic patients died, in spite of haemodialysis treatment in three. All the patients with nephrotic syndrome survived, though two were known to have persistent proteinuria. Two of the three were treated with steroids, but in only one did it seem likely that improvement was due to the steroid therapy. A transient proteinuria (trace to $1+$ ) was demonstrated in two-thirds of patients carefully followed with serial urine examinations by Coon, Duff, Hodgson, and Dennis (1953). This is clearly unrelated to sensitivity reactions, and one has to presume that it was due to direct renal damage.

\section{Toxicity of Phenindione}

That phenindione was responsible for the sensitivity reactions associated with its use is highly probable for a number of reasons. Firstly, it was in most cases the chief or only drug being administered. Secondly, the temporal relation is reasonably constant, the onset averaging 29.7 days (range 11 to 66 days) for first courses of the drug. Thirdly, a small test dose provoked a recurrence of symptoms in some patients (Makous and Vander Veer, 1954 ; Brooks and Calleja, 1960), as did second courses of the drug in the present cases and in those of Bingle and Shine (1959) and Juel-Jensen (1959), the onset being earlier with a second course. Fourthly, other prothrombinopenic drugs, such as warfarin and ethyl biscoumacetate, given to the same patients produced no adverse reactions. Fifthly, the reported lesions are all consistent with sensitivity reactions, although, in contrast to Perkins (1962), we exclude the case of breast gangrene reported by Kipen (1961).

Although Burns and Desmond (1958) stated that the presence of a " modified benzene ring" in a compound made it potentially dangerous there is no evidence that we can find to show that the five-membered carbon ring in phenindione (see Formula) is what is responsible for its toxicity. Perkins (1962) speculated that phenindione's known uncoupling action on

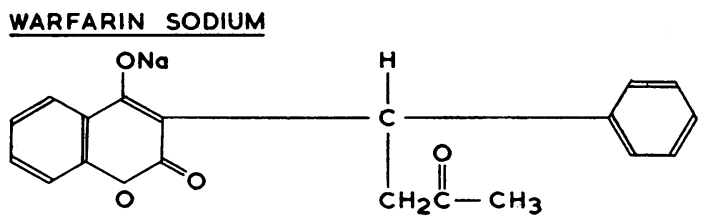<smiles>CCCN1OCc2ccccc2C1=O</smiles>

oxidative-phosphorylation reactions might be the responsible factor ; and in this connexion it is pertinent to recollect that isocarboxazid, which also has such an action, has caused liver damage in some patients.

The incidence of serious sensitivity reactions is not entirely clear because many of the reported reactions do not mention the total patients treated. However, from the reports of prospective

Cases of Renal Damage Attributed to Phenindione Therapy

\begin{tabular}{|c|c|c|c|c|c|c|c|}
\hline Authors & $\begin{array}{c}\text { Onset of } \\
\text { Symp- } \\
\text { toms in } \\
\text { Days }\end{array}$ & Clinical Presentation & Urine & $\begin{array}{c}\text { Blood } \\
\text { Urea } \\
\text { mg./100 } \\
\text { ml. }\end{array}$ & Histology & Treatment & Comment \\
\hline $\begin{array}{l}\text { Baker and } \\
\text { Williams } \\
(1963)\end{array}$ & $\begin{array}{l}17 \\
24 \\
30\end{array}$ & $\begin{array}{l}\text { Rash, haematuria } \\
\text { Jaundice, fever } \\
\text { Further rash, anuria }\end{array}$ & Anuria & 375 & $\begin{array}{l}\text { Interstitial cellular in- } \\
\text { filtration. Some tub- } \\
\text { ular cell necrosis and } \\
\text { glomerular changes } \\
\text { 2nd biopsy } 26 \text { days later } \\
\text { showed remarkable } \\
\text { recovery }\end{array}$ & $\begin{array}{l}\text { Dialysis (2) } \\
\text { Presnisolone for } 25 \text { days. } \\
100 \text { mg. daily started } \\
2 \text { days after first dia- } \\
\text { 1ysis } \\
\text { 2nd dialysis done } 4 \text { days } \\
\text { after the first }\end{array}$ & $\begin{array}{l}\text { Rash had faded and jaundice was } \\
\text { waning when prednisolone was } \\
\text { started } \\
\text { Outcome-recovery }\end{array}$ \\
\hline $\begin{array}{l}\text { Barritt and } \\
\text { Jordan } \\
(1960)\end{array}$ & 12 & $\begin{array}{l}\text { Rash, fever, diarrhoea. Renal } \\
\text { failure developed }\end{array}$ & Oliguria & 560 & $\begin{array}{l}\text { Extensive renal tubular } \\
\text { necrosis }\end{array}$ & - & $\begin{array}{l}\text { Phenindione used previously. Had } \\
\text { a course for } 18 \text { days which } \\
\text { ended } 2 \text { weeks before starting } \\
\text { second course. Died } 4 \text { weeks } \\
\text { after appearance of rash }\end{array}$ \\
\hline $\begin{array}{l}\text { Brooks and } \\
\text { Calleja } \\
(1960)\end{array}$ & $\begin{array}{l}16 \\
24 \\
30\end{array}$ & $\begin{array}{l}\text { Fever } \\
\text { Rash } \\
\text { Jaundice }\end{array}$ & $\begin{array}{l}\text { Alb. }++++\cdot \\
\text { Granular casts. } \\
\text { Red and white } \\
\text { blood cells }\end{array}$ & 10 & - & $\begin{array}{l}\text { A.C.T.H. } 40 \text { units daily } \\
\text { for } 27 \text { days. Started } \\
\text { on } 35 \text { th day of illness } \\
\text { when jaundice at its } \\
\text { height }\end{array}$ & $\begin{array}{l}\text { Improved. } \\
2 \text { weeks later a provocative test } \\
\text { was done by giving } 50 \text { mg. } \\
\text { phenindione daily for } 2 \text { days. } \\
\text { This resulted in rash on 3rd } \\
\text { day }\end{array}$ \\
\hline $\begin{array}{l}\text { Galea et al. } \\
\quad(1963)\end{array}$ & $\begin{array}{l}18 \\
25 \\
31 \\
36 \\
40 \\
42\end{array}$ & $\begin{array}{l}\text { Bronchospasm } \\
\text { Sore throat, pruritus } \\
\text { Rash } \\
\text { Loin pain, nausea, diarrhoea } \\
\text { Haematuria, small haematemesis } \\
\text { Vomiting, abdominal distension, } \\
\text { wheezing, renal failure } \\
\end{array}$ & Anuria & 468 & $\begin{array}{l}\text { Interstitial cellular infil- } \\
\text { tration. Tubular ne- } \\
\text { crosis. } \\
\text { changes }\end{array}$ & Dialysis & $\begin{array}{l}\text { Developed hypotension after dia- } \\
\text { lysis and died } 12 \text { days later }\end{array}$ \\
\hline$\underset{\text { Wong }}{\text { Hollman }}$ and & 63 & $\begin{array}{l}\text { Purpura, oedema, tenderness of } \\
\text { both ankles } \\
\text { Nephrotic syndrome }\end{array}$ & $\begin{array}{l}\text { Alb. }++++\cdot \\
\text { Casts, white } \\
\text { and red } \\
\text { blood cells }\end{array}$ & 39 & - & - & $\begin{array}{l}\text { Improved when drug was stopped. } \\
\text { Albuminuria persisted } 3 \text { months } \\
\text { after anticoagulant was stopped }\end{array}$ \\
\hline $\begin{array}{r}\text { Kirkeby } \\
(1954)\end{array}$ & $\begin{array}{l}28 \\
35 \\
54 \\
\end{array}$ & $\begin{array}{l}\text { Rash } \\
\text { Stomatitis, agranulocytosis, jaun- } \\
\text { dice } \\
\text { Renal failure }\end{array}$ & $\begin{array}{l}\text { Oliguria } \\
\text { Alb. trace }\end{array}$ & 286 & - & $\begin{array}{l}\text { Cortisone for } 2 \text { weeks. } \\
\text { Started with } 100 \mathrm{mg} \text {. } \\
\text { daily, later increased } \\
\text { to } 300 \mathrm{mg} \text {. daily }\end{array}$ & $\begin{array}{l}\text { Initial improvement, but } 3 \text { days } \\
\text { after cortisone was stopped car- } \\
\text { diac failure and renal failure } \\
\text { developed. Died } 10 \text { days later } \\
\end{array}$ \\
\hline Pearce (1963) & 14 & Rash, lymphadenopathy, nausea & - & $\begin{array}{l}170 \text { to } \\
230\end{array}$ & - & - & Improved \\
\hline $\begin{array}{l}\text { Postgrad. } \\
\text { Med. Sch. } \\
(1960)\end{array}$ & $\begin{array}{l}60 \\
64\end{array}$ & $\begin{array}{l}\text { Fever, rash, lymphadenopathy } \\
\text { Renal failure }\end{array}$ & $\begin{array}{l}\text { Oliguria } \\
\text { Alb. nil }\end{array}$ & $\begin{array}{l}120 \text { to } \\
-525\end{array}$ & $\begin{array}{l}\text { Damage of proximal } \\
\text { tubular cells. Inter- } \\
\text { stitial cellular infiltra- } \\
\text { tion } \\
\end{array}$ & Dialysis & $\begin{array}{l}\text { Died of pulmonary hypertension } 8 \\
\text { days after dialysis. Histology at } \\
\text { necropsy was similar to that at } \\
\text { biopsy }\end{array}$ \\
\hline Гait (1960) & $\begin{array}{l}49 \\
63\end{array}$ & $\begin{array}{l}\text { Diarrhoea } \\
\text { Nephrotic syndrome }\end{array}$ & Alb. ++++ & 52 & - & $\begin{array}{l}\text { Prednisone started with } \\
30 \mathrm{mg} \text {. daily, later re- } \\
\text { duced to maintenance } \\
\text { dose of 5-10 mg. daily }\end{array}$ & $\begin{array}{l}\text { Improved but albuminuria persis- } \\
\text { ted. Still on maintenance pred- } \\
\text { nisone after } 10 \text { months }\end{array}$ \\
\hline
\end{tabular}


trials of phenindione therapy it would appear that severe reactions occur in about $0.2 \%$ of patients. Skin rashes, other than severe dermatitis, occur in $0.5 \%$ to $2 \%$ of most large series and lead to withdrawal of the drug. These figures, and particularly those for the serious reactions, may well underestimate the true situation, because it is clear from the reported cases that the role of phenindione was sometimes appreciated only late in the illness or after a second course of the drug. It is likely, therefore, that cases of phenindione sensitivity have gone unrecognized, and, of course, not all the observed cases will have been published.

\section{Choice of Anticoagulant}

In view of these serious though uncommon side-effects we have stopped using phenindione in our department for the treatment of new patients, though it is being continued in those who have already had it for some months. We now employ warfarin sodium for anticoagulant treatment because long experience in the U.S.A. has shown it to give an even depression of the prothrombin time (Fremont and Jagendorf, 1957) and to be only rarely associated with sensitivity reactions. It was in fact substituted successfully for phenindione in three of the reported cases. Two cases of dermatitis (Adams and Pass, 1960 ; Shah and Goodluck, 1962), and one case each of diarrhoea (Clatanoff and Meyer, 1956), urticaria (Sheps and Gifford, 1959), and alopecia (Bradley, 1964) are the only reports we can find of such reactions. A curious syndrome of purplish discoloration of the hands and feet with both warfarin and dicoumarol was reported by Feder and Auerbach (1961), but its genesis is not clear.

Absorption of warfarin from the gut is complete and of short duration, while its elimination phase is relatively slow (O'Reilly, Aggeler, and Leong, 1963). Thus therapeutic prolongation of the prothrombin time is achieved as quickly with warfarin as with phenindione (Kerrin, Guidot, and Wilhelm, 1957), but, since the duration of action is longer, the first maintenance dose is not given until the third day of treatment (Toohey, 1958). A comparative study of warfarin and phenindione by Rodman, Ryan, Pastor, and Hollendonner (1959) showed that they were equally easy to control and that there was no significant difference in the incidence of haemorrhagic complications.

\section{Summary}

Nephrotic syndrome and stomatitis due to phenindione sensitivity are reported in two patients. In both there was a return of symptoms with a second course of the drug. Eight patients with severe renal damage attributed to phenindione have now been reported, and the details of these cases are reviewed.

Severe sensitivity reactions occur in a minimum of $0.2 \%$ of patients treated with phenindione. Rashes severe enough to cause withdrawal of the drug occur in at least $1 \%$.
In view of these sensitivity reactions we no longer use phenindione in the treatment of new patients. We believe warfarin to be a safer drug because sensitivity reactions with it are rare. Warfarin acts as quickly as phenindione, is as easy to control, and has a similarly low incidence of haemorrhagic complications.

We acknowledge gratefully the assistance given to one of us (A. H.) by the Rockefeller Committee of University College Hospital Medical School and to the other (H. O. W.) by Smith and Nephew Ltd., from whom she holds a research fellowship. Dr. E. J. Ross kindly allowed us to publish the details of Case 2. We thank Professor M. D. Milne for his kind help and advice.

\section{BIBLIOGRAPHY}

Adams, C. W., and Pass, B. J. (1960). Circulation, 22, 947.

Ager, J. A. M., and Ingram, G. I. C. (1957). Brit. med. f., 1, 1102

Ager, J. A. M., and Ingram, G. I. C. (1957). Brit. med. F., 1, 1102.

Barritt, D. W., and Jordan, S. C. (1960). Lancet, 1, 1309.

Bingle, J., and Shine, I. (1959). Ibid., 2, 377.

Borchgrevink, C. F. (1960). Acta med. scand., 168, Suppl. No. 359.

Bradley, M. H. (1964). F. Amer. med. Ass., 187, 36.

Brit. med. f., 1963, 1, 801.

Brooks, R. H., and Calle;a, H. B. (1960). Ann. intern. Med., 52, 706. Brown, K. W. G., and MacMillan, R. L. (1954). Amer. F. med. Sci., 227,

526.

Clatanoff, D. V., and Meyer, O. O. (1956). Arch. intern. Med., 97, 753.

Coon, W. W., Duff, I. F., Hodgson, P. E., and Dennis, E. W. (1953) Ann. Surg., 138, 467.

Deming, J. W. (1960). f. La med. Soc., 112, 463.

East, E. N., and Beamish, R. E. (1957). Canad. med. Ass. 7., 77, 1028

Feder, W., and Auerbach, R. (1961). Ann. intern. Med., 55, 911.

Fremont, R. E., and Jagendorf, B. (1957). F. Amer. med. Ass., 165, 1381 .

Galea, E. G., Young, L, N., and Bell, J. R. (1963). Lancet, 1, 920.

Guthaner, E. (1960). Brit. med. f., 1, 202.

Hunt, J. H. C. (1960). Ibid., 1, 202.

Johnman, L. (1957). Scot. med. f., 2, 330.

Jones, N. L. (1960). Brit. med. Ұ., 2, 504.

Juel-Jensen, B. E. (1959). Ibid., 2, 173.

Kerrin, H. F., Guidot, J., and Wilhelm, S. K. (1957). Angiology, 8, 302. Kipen, C. S. (1961). New Engl. F. Med., 265, 638.

Kirkeby, K. (1954). Lancet, 2, 580.

Langley, R. B., and McCredie, K. B. (1963). N.Z. med. 7., 62, 243.

Makous, N., and Vander Veer, J. B. (1954). f. Amer. med. Ass., 155 739.

Mather, G., and Riley, C. (1960). Brit. med. F., 2, 506.

Mayer, A. C. (1954). Lancet, 2, 708.

O'Reilly, R. A., Aggeler, P. M., and Leong, L. S. (1963). f. clin. Invest., 42, 1542 .

Pastor, B. H., and Tetreault, A. F. (1956). F. Amer. med. Ass., 161, 873

Payne, R. W. (1960). Brit. med. F., 2. 667.

Pearce, J. M. S. (1963). Lancet, 1, 1158.

Perkins, J. (1962). Ibid., 1, 125, 127.

Pertal, R. W., and Emanuel, R. W. (1961). Brit. med. F., 2, 1318.

Postgraduate Medical School of London (1960). Ibid., 2, 1219.

Rodman, T., Ryan, C. S., Pastor, B. H., and Hollendonner, W. J. (1959) Amer. F. Med., 27, 415.

Shah, V. V., and Goodluck, P. L. (1962). Curr. med. Pract., 6, 139.

Sheps, S. G., and Gifford, R. W. (1959). Amer. ₹. Cardiol., 3, 118.

Smith, P. C. (1959). Ann. intern. Med., 51, 617.

Stafford, J. L. (1961). Symposium on Anticoagulant Therapy. Ed. Pickering, G. W. Harvey and Blythe, London.

Tait, G. B. (1960). Lancet, 2, 1198.

Tashjian, A. H., and Leddy, J. P. (1960). Arch. intern. Med., 105, 121.

Tashiian, A. H., and Leddy, J. P. (1960).

Townsend, S. R., Fay, K. J., Downing, J. R., Laing, R., and Cameron, D. G. (1953). Canad. med. Ass. F., 69, 149.

Wallace, D. C. (1960). Med. F. Aust., 47, 934. 